\title{
Agency Conflicts, Socioemotional Wealth, and the Debt Maturity Structure of Family Firms: A Critical Analysis
}

\author{
Oscar Domenichelli ${ }^{1}$ \\ ${ }^{1}$ Department of Management, Faculty of Economics “Giorgio Fuà”, Università Politecnica delle Marche, Ancona, \\ Italy
}

Correspondence: Oscar Domenichelli, Department of Management, Faculty of Economics "Giorgio Fuà", Università Politecnica delle Marche, Piazzale R. Martelli, 8, 60121, Ancona, Italy. Tel: 39-071-220-7193. E-mail: o.domenichelli@univpm.it

Received: July 15, 2017

Accepted: July 27, 2017

Online Published: August 10, 2017

doi:10.5539/ijef.v9n9p40

URL: https://doi.org/10.5539/ijef.v9n9p40

\begin{abstract}
This paper aims to study the impact of the distinctive agency and socioemotional features of family firms on their debt maturity choices using a literature analysis of this topic, still substantially unexplored. Therefore, the paper examines the relationships between owners and managers; majority and minority shareholders, and family shareholders and family outsiders; and owners and creditors. The analysis suggests that the propensity of family businesses to use long-term debt depends on the generation leading the family firm, family blockholders, motivation for expropriating minority shareholders, family outsiders and their socioemotional orientation. Much still remains to be empirically studied. One interesting issue to explore further would be the influence of country-specific factors worldwide, in combination with firm-specific characteristics relating to agency conflicts and socioemotional wealth, on the debt maturity decisions of family firms, compared to non-family ones. Given the international importance of family firms, and their widespread presence and activity worldwide, additional empirical results on this topic may help governments adopt specific policies, that will better support family businesses, in light of their peculiar and unique economic and non-economic aspects.
\end{abstract}

Keywords: family firms, non-family firms, agency conflicts, socioemotional wealth, debt maturity

\section{Introduction}

The literature on the financing decisions of firms has generated two main streams of research, on the one hand, addressing capital structure, which can be defined as the mix between debt and equity and, on the other, debt maturity, which is the choice between short- and long-term debt.

If we look at the latter field of study, empirical analysis, albeit more recent, has demonstrated over the last four decades that agency conflicts between owners and managers (for instance, Rajan \& Winton, 1995; Datta, Iskandar-Datta, \& Raman, 2005; Jiraporn \& Kitsabunnarat, 2007), majority and minority owners (for example, La Porta, Lopez-De-Silanes, \& Shleifer, 1999; Claessens, Djankov, Fan, \& Lang, 2002; Faccio \& Lang, 2002; Dyck \& Zingales, 2004) and owners and creditors (e.g., Jensen \& Meckling, 1976; Myers, 1977; Barnea, Haugen, \& Senbet, 1980; Barclay \& Smith, 1995) have had a considerable impact on the debt maturity structures of firms. Broadly speaking, agency conflicts between principals and agents and related costs arise from adverse selection and moral hazard. Adverse selection takes place when the principal selects an agent who is less able, committed, industrious, or ethical than the principal expected or whose interests are less aligned than the principal originally believed. Moral hazard, instead, originates from the commission or omission of actions by an agent that are harmful to the principal (Chrisman, Chua, \& Litz, 2004).

When it comes to considering family firms, it can be argued that they show distinctive financial and managerial structures, since they have concentrated and poorly diversified ownership, longer investment horizons, active involvement of the family members in the management of their firms, and a specific generation leading the family firm (the founder or a later generation) (Cheng, 2014). These peculiarities are likely to influence the magnitude and type of agency conflicts in family firms, which are indeed worth considering and interpreting, especially with reference to their debt maturity structures.

Further, family firms also exhibit unique non-financial features, related to the entangled nature of family and 
family business and leading to the enhancement of autonomy and control, family cohesiveness, supportiveness and loyalty, as well as harmony, pride, family name recognition, respect, and status (Zellweger, Nason, Nordqvist, \& Brush, 2011). Interestingly, Gomez-Mejia, Takacs-Haynes, Nuñez-Nickel, Jacobson, and Moyano-Fuentes (2007) define socioemotional wealth as a set of several non-financial aspects, including identity, the ability to exercise family influence, and the perpetuation of a family dynasty. In turn, this socioemotional orientation generates specific governance issues and behavioural differences between family and non-family firms (Kalm \& Gomez-Mejía, 2016), and constitutes a further possible explanation for the proportion of shortversus long-term debt acquired by family businesses, which can be taken into account together with agency facets.

Therefore, the distinctive agency and socioemotional dimensions of family firms just mentioned are expected to influence the debt maturity decisions of family firms. However, there is little financial literature that has analysed the relationship between debt maturity and family firms (Díaz-Díaz, García-Teruel, \& Martínez-Solano, 2016), and the connection between socioemotional wealth and debt maturity is virtually absent from the ongoing debate. Hence, this study contributes to the existing literature by critically analysing the possible relationships between agency conflicts, socioemotional issues and debt maturity in family firms, in terms of the structure of their proprietorship and management, and then proposing conceivable paths for future empirical discussion in the field. The main practical implication is that the results of further empirical research on this topic may lead governments to adopt specific policy measures, that will better support family firms, considering their peculiar and unique economic and non-economic characteristics.

This study reviews and comments on the main relevant literature, which has been published mostly in leading finance journals, and the remainder of this paper is organized as follows. The next section offers a definition of the family firm, and highlights its financial and non-financial characteristics. The article discusses - from the point of view of family firms and via studying agency conflicts, socioemotional issues and debt maturity - the following topics: The relationships between owners and managers; majority and minority shareholders, and family shareholders and family outsiders; and owners and creditors, in Section Three. Section Four concludes the article.

\section{Family Firms}

\subsection{The Definition of the Family Firm}

Family firms account for a large share of the world economy in many countries in terms of enterprises, gross domestic product and employment, for example, in Germany (Klein, 2000), The Netherlands (Floren, 1998), Italy (Corbetta, 1995) and the United States (Astrachan \& Shanker, 2003) (Note 1). More than 50\% of enterprises in the European Union are family-owned; in Latin America, they represent between 65\% and 90\% per cent of firms, and in the United States, they constitute over 95\% of businesses (PricewaterhouseCoopers, 2007). These firms also generate $64 \%$ of the gross domestic product in the United States and $75 \%$ in most other countries. Family businesses employ $80 \%$ of the United States workforce and $85 \%$ of the working population worldwide. A total of $37 \%$ of Fortune 500 companies are family-controlled (Poza, 2007), and overall, family businesses represent approximately 46\% of the Standard and Poor's (S\&P) 1500 index firms (Chen, S., Chen, X., $\&$ Cheng, 2008).

The importance of family firms around the world has stimulated the research on family business since the late 1980s (Benavides-Velasco, Quintana-García, \& Guzmán-Parra, 2013), even if those studies on family firms have become relevant only recently (among others: Rogoff \& Heck, 2003; Chrisman, Steier, \& Chua, 2008; Milton, 2008; Zahra, Hayton, Neubaum, Dibrell, \& Craig, 2008; Chua, Chrisman, \& Bergiel, 2009; Debicki, Matherne, Kellermanns, \& Chrisman, 2009; Steier, Chua, \& Chrisman, 2009).

Nonetheless, in spite the acknowledged importance of family firms, no precise definition of family firm is widely accepted. Often family firms are identified on the basis of the percentage of shares owned by the family that has the control over the business (among others: Barth, Gulbrandsen, \& Schøne, 2005; Amore, Minichilli, \& Corbetta, 2011) or the presence of a family member in top management or on their Boards (Anderson \& Reeb, 2003). A few authors use multiple operational definitions of family firms (for example, Astrachan \& Shanker, 2003), while a few others employ scales to consider the different kinds of family participation (Astrachan, Klien, \& Smyrnios, 2002) or utilize family firm typologies (Sharma, 2003). Villalonga and Amit (2010) consider four possible definitions of family firms, through which they explicitly take into account family involvement, when these firms are in their second or later generations. Cheng (2014, p. 150) defines a family firm as an enterprise "in which the founders or descendants of the founding family continue to hold positions in the top management, serve on the board, or are blockholders". Other studies examine, in particular, the role of founding family firms 
on investment policy (Anderson, Duru, \& Reeb, 2012), firm performance (Anderson \& Reeb, 2003) and agency costs of debt (Anderson, Mansib, \& Reeb, 2003).

It is noteworthy as well to stress that the use of a common definition of the family firm has both advantages and drawbacks. From the first point of view, it permits comparisons of different researches, provides objectivity to the actual classification of family and allows the results to be more generalizable (Cheng, 2014). Nevertheless, if we look at the disadvantages, a unique definition of family firm can be ambiguous, as it will not then consider fundamental distinctions that do exist in different legal and institutional frameworks (Carney, 2005; Dyer, 2006).

As the objective of this paper is analytical, not empirical, it operationalizes the concept of family firm by using the approach of the World Economic Forum (2013, p. 7), which considers a family firm to be a firm in which “... the founding family exercises significant influence through its equity ownership, voting control and/or management ..." and where a family is represented by "A group of individuals related by blood, marriage or adoption, who have a claim on the family business or other common family assets". Indeed, to some extent, this definition is broad enough to encompass the influence of families in the actual management and control of family firms. In fact, this definition is even broader than those already used in many studies (e.g., Anderson \& Reeb, 2003; Villalonga \& Amit, 2006; Ali, Chen, \& Radhakrishnan, 2007; Cheng, 2014), and it may include the involvement of a family member in a firm, as a director, manager, blockholder or just a relative, no matter the generation being considered.

\subsection{The Characteristics of Family Firms}

The exclusive characteristics of family firms have motivated considerable research on family firms. Hence, it is important to discuss their features, which are specifically relevant for this current effort, as mentioned in the Introduction. From this point of view, these features can be divided into two main groups. The first concerns the financial aspects of the family firm, and the second addresses the non-financial ones; however, both have important effects on the debt maturity structures of family firms.

As far as the first group is concerned, first, family owners tend to hold undiversified and concentrated equity positions in their firms (Ali et al., 2007). This means, on the one hand, that most of their private wealth is invested in the firm, and, on the other hand, the founders or relatives or descendants are the major shareholders.

Secondly, family members actively manage their firms, either as top executives or directors and this input allows them to effectively and personally represent their preferences (Cheng, 2014); thus, they have an enormous influence on the strategies of their firms.

When considering the second group of characteristics, family firms are interested in socioemotional wealth. Socioemotional wealth is a series of non-financial aspects that family owners derive from their business (Gomez-Mejia et al., 2007), as previously defined. To preserve and enhance that socioemotional wealth, families must maintain control and influence over the firm's operations and ownership, pass on the business to future generations, and also sustain the family's image and reputation (Naldi, Cennamo, Corbetta, \& Gomez-Mejia, 2013).

\section{Agency Conflicts, Socioemotional Wealth, and Debt Maturity}

\subsection{The Relationships between Owners and Managers in Family Firms: Agency Conflicts, Socioemotional Wealth, and Debt Maturity}

The agency conflicts between owners and managers (Berle \& Means, 1932; Jensen \& Meckling, 1976), i.e., the so-called "Agency Problem I" (Villalonga \& Amit, 2006), arise from the separation of ownership from control (Fama \& Jensen 1983a) when there is divergence of interests between owners and managers, so that the latter, as shareholder agents, may be tempted to undertake behaviours that favour only them, rather than creating shareholder wealth. This circumstance may happen through various activities. For example, opportunistic managers can "build empires", by causing the firm to grow beyond its optimal size or maintaining unutilized resources, so as to increase their personal utility from status, power, compensation and prestige (Chen, Lu, \& Sougiannis, 2012). Secondly, managers can strive for diversification by investing in projects with negative net present values or decrease the firm's outstanding debt (Friend \& Lang, 1988) to reduce their undiversifiable employment risk (Amihud \& Lev, 1981). Another opportunistic behaviour is entrenching investment, i.e., managers can entrench themselves by making manager-specific investments, which then make it expensive for shareholders to replace them (Shleifer \& Vishny, 1989). Further, according to some researchers, anti-takeover provisions allow selfish managers to protect themselves from the disciplinary role of the market for corporate control, thus worsening agency conflicts between them and the stockholders (Straska \& Waller, 2014).

Agency conflicts between owners and managers are likely to be greater when proprietorship is dispersed among 
several shareholders, so managers can more easily exploit the information asymmetries, existing between them and the owners. These conflicts are eliminated when a firm is managed by a single owner (Fama \& Jensen, 1983b). Accordingly, the presence of blockholders limits managerial opportunism, as large shareholders have a strong incentive to commit themselves to control activities (Shleifer \& Vishny, 1986; McConnell \& Servaes, 1990). In fact, large shareholders' returns on their shares is larger than the monitoring cost on managers (Shleifer \& Vishny, 1986). Moreover, sometimes, blockholders are institutional shareholders, which have excellent competences, allowing them to better monitor managers when compared to minority shareholders (Sun, Ding, Guo, \& Li, 2016).

Further still, the conflicts in question tend to decrease when managerial shareholding increases, as this leads to an alignment of the interests of managers and shareholders (Jensen \& Meckling, 1976). However, in the opinion of some authors (Brailsford, Oliver, \& Pua, 2002; Florackis \& Ozkan, 2009; Sun et al., 2016), this alignment of interests holds true only up to a certain level of managerial ownership, as it disappears when managerial shareholding is high, because managers wish to avoid considerable debt, thereby increasing their own undiversifiable employment risk (Amihud \& Lev, 1981), even if doing so implies foregoing positive-NPV investment projects.

Another way to hinder selfish managerial behaviours is to reduce free cash flow, which can be inefficiently employed by managers to the detriment of shareholders (managerial overinvestment or free cash flow problem) (Lopez-Gracia \& Mestre-Barberá, 2015). This reduction can be obtained through increasing leverage (Jensen, 1986). Managers can also be further disciplined by decreasing debt maturity, since their behaviour is externally controlled by creditors, through frequent debt roll-overs (Stulz, 2000).

It could be argued that family firms should not need specific incentive mechanisms, and neither should they need disincentive mechanisms to reconcile managerial interests with those of proprietors, since as contended by some researchers, family firms should not be affected by major agency conflicts between owners and managers (Becker, 1974; Eisenhardt, 1989; Daily \& Dollinger, 1992). This issue can be further explicated as follows.

First, as described by Chrisman et al. (2004), agency costs between managers and shareholders occur when the former take care of their own interests at the expense of the latter. However, family firms try also to achieve noneconomic objectives, and to the extent that managers pursue them, for example, by providing jobs for their less able members, actually there are no agency costs. Furthermore, family members are likely to create a Board of Directors that will support the family preferences and thus make decisions that satisfy their socioemotional needs (Gomez-Mejia, Cruz, Berrone, \& De Castro, 2011). Sometimes, investors may believe that a family firm has governance problems because of its strong orientation to socioemotional wealth. Therefore, listed family firms may actually appoint outside directors to signal both their own quality and legitimacy (Kalm \& Gomez-Mejía, 2016) and further to be able to raise riskier, namely, long-term debt, to finance long-term investments.

Secondly, agency costs between managers and owners are, however, insignificant in most family firms, owing to the family block ownership. In fact, large family shareholders have a strong motivation to effectively monitor all managers (Shleifer \& Vishny, 1986), due to their undiversified portfolios, concentrated ownership, and firm survival concern (Cheng, 2014). Therefore, they can then ease takeover efforts, remove managers who fail to maximize their wealth and obtain more precise information on managerial performance (Chahine, 2007). Specifically, in the case of founding-family firms, these possibilities and incentives are expected to be significant, since usually family members have invested most of their private wealth into a company that is generally not well diversified; they also are on the Board of Directors and they may have firm- and market-specific knowledge that improves their capability to closely and properly monitor the managers (Andres, 2008). These better incentive mechanisms can lead to fewer agency costs between owners and managers, so that these family businesses may avoid frequent debt renewals, since they do not need them as a control tool over managers, and thus they may utilize debt with longer maturities.

However, according to Schulze, Lubatkin, Dino and Buchholtz (2001), the agency costs in question can be high in family firms when there is private ownership, because, first of all, this kind of ownership reduces external governance mechanisms, and secondly, the efforts to maximize one's welfare can cause individuals to act in a way that does not develop a common well-being.

Interestingly, Blanco-Mazagatos, de Quevedo-Puente and Castrillo (2007) introduced a dynamic view of the agency conflicts between owners and managers in family businesses. In fact, they contend that, in first-generation family firms, these agency conflicts are low because, on the one hand, there is a coincidence between ownership and management, and on the other hand, the relationships within a nuclear family are closed, 
strong, and characterized by altruism. However, as time passes, and the successors take their place in the business, the agency conflicts in question tend to grow. In fact, ownership and management become more dispersed, which increases the likelihood of information asymmetries and the occasion for the opportunistic behaviour of managers. Since short-term debt gives lenders the flexibility to effectively monitor managers with minimum effort (Rajan \& Winton, 1995), reducing debt maturity is also an effective way to minimize the agency conflicts between owners and managers, as previously illustrated (Stulz, 2000). Therefore, selfish managers will prefer long-term debt to avoid the potential discipline of external monitoring (Datta, Iskandar-Datta, \& Raman, 2005). Consequently, when the conflicts of interests between managers and shareholders are considerable, that is, when a family firm is older, managers will prefer longer debt maturity (Domenichelli, 2015).

3.2 The Relationships between Majority and Minority Shareholders, and between Family Shareholders and Family Outsiders in Family Firms: Agency Conflicts, Socioemotional Wealth, and Debt Maturity

The agency conflicts that occur between different types of shareholders primarily refer to those between the controlling owners (agents) and non-controlling owners (principals), labelled as "Agency Problem II" (Villalonga \& Amit, 2006), which in family businesses, is likely to overshadow "Agency Problem I" (Villalonga, Amit, Trujillo, \& Guzmán, 2015) earlier examined here. However, the valuation premium associated with family firms, as shown by numerous studies (among others, Anderson \& Reeb, 2003; Villalonga \& Amit, 2006; Andres, 2008), demonstrates that the benefit of the reduction in "Agency Problem I" is greater than the higher costs related to "Agency Problem II".

Agency Problem II emerges as large family shareholders can expropriate minority shareholders through excessive compensation, related-party transactions, special dividends, and financial transactions that damage the interests of minorities (Johnson, La Porta, Lopez-De-Sinales, \& Shleifer, 2000; Burkart, Panunzi, \& Shleifer, 2003; Anderson \& Reeb, 2003). This possibility derives from the divergence between voting rights and cash-flow rights, allowing family controlling shareholders to bear little of the wealth consequences of decisions they have made as controllers (Bebchuk, Kraakman, \& Triantis, 2000). This divergence can be achieved through dual-class shares, pyramids and cross shareholdings (Villalonga et al., 2015), as well as disproportionate Board representation and voting agreements between the controlling family and non-family shareholders (Villalonga \& Amit, 2009). Hence, large shareholders may avoid using their personal financial resources, in order to enhance wealth expropriation from minorities, and employ long-term debt to strengthen their own control. Coherently, Shyu and Lee (2009) found a negative relationship between excess control rights and short-term debt for listed family firms, a finding that suggests that the discrepancy between control rights and cash flow rights offers an opportunity for the controlling shareholders, in family firms, to expropriate wealth from their minority shareholders.

Nonetheless, family controlling shareholders have a lower motivation for expropriating minority shareholders, owing to their concerns with the firm's long-term survival and its reputation (Anderson, Mansib, \& Reeb, 2003; Croci, Doukas, \& Gonenc, 2011). This can be explained by the issue of socioemotional wealth, which implies passing on the business to future generations and supporting the family image and name. Therefore, even if the presence of pyramid structures decreases debt maturity, this effect is lower for family firms (Díaz-Díaz et al., 2016). Interestingly, although large non-controlling shareholders may protect minority shareholders from wealth extraction, sometimes these shareholders may instead choose to collude with the controlling shareholder, if it is in their mutual interest (Cai, Hillier, \& Wang, 2016); thus, the existence of a second largest family shareholder, in a family-owned firm, reduces the access to long-term debt (Díaz-Díaz et al., 2016).

Another important issue, as defined more recently by Villalonga et al. (2015) "Agency Problem IV", refers to the conflicts of interest between family shareholders (agents) and family outsiders (superprincipal), that is, between the family shareholders and the family at large (non-shareholders, non-Board members and non-managers). Like any other agency conflict, this one arises from the divergence of goals of principal and agent. Indeed, family shareholders, as part of the family, probably share some or all their principals' objectives, such as protecting and enhancing the family's legacy, reputation, values, unity, culture, vision and harmony; procuring employment for family members; protecting the environment; and helping the community (Villalonga et al., 2015). Specifically, a major motivation of owners is to preserve their socioemotional wealth, and they may take less efficient or higher-risk decisions to achieve this desired result (Kalm \& Gomez-Mejía, 2016). As the family's desire to avoid socioemotional losses is considerable, this objective influences the long-term performance of family firms and may be the reason why the empirical research has shown mixed results on the effects of family ownership on firm performance (Anderson \& Reeb, 2003; Villalonga \& Amit, 2006; Barontini \& Caprio, 2006; Sacristán-Navarro, Gómez-Ansón, \& Cabeza-García, 2011). 
Nevertheless, family shareholders may instead have certain objectives that may diverge from those of the family outsiders, and specifically concern some financial aspects of the business, such as maximizing financial returns, increasing distributions, and having liquidity or even exit options (Villalonga et al., 2015). Consequently, when there is an "Agency Problem IV" and weak or absent discipline role of the market for corporate control - thus forcing family firms to maximize wealth creation -, family shareholders may wish to decrease the debt maturity to signal to creditors their personal more credible commitment to value creation. In fact, frequent renewals imply recurrent control by lenders and thus a higher risk of financial distress, since some debts may not be rolled over.

\subsection{The Relationships between Owners and Creditors in Family Firms: Agency Conflicts, Socioemotional Wealth, and Debt Maturity}

If we look at the agency conflicts between owners (agents) and creditors (principals), the so-called "Agency Problem III", (Villalonga et al., 2015), Jensen and Meckling (1976) assert that outstanding debt contracts may create incentives to overinvest to the detriment of the lenders. Specifically, shareholders of a leveraged firm have incentives to substitute low-risk investments for high-risk ventures; this change in strategy causes a risk shifting problem, but it may enable owners to increase their wealth at the expense of their creditors (Lopez-Grazia \& Mestre-Barberá, 2015). Further, Myers (1977) studied the underinvestment problem, which occurs when shareholders pass up valuable investment opportunities because profits from these investments would benefit mainly or only the creditors. Anticipating the possibility of these opportunistic behaviours, creditors will require high returns and thus increase the firm's debt financing costs (Villalonga et al., 2015).

Dang and Phan (2016) quote Myers (1977), Barnea et al. (1980), and Childs, Mauerb and Steven (2005) to contend that the choice of short-term debt both alleviates the agency problems of underinvestment and those of overinvestment. As these problems increase when firms have significant growth opportunities, Barclay and Smith (1995) found that firms that have more growth options in their investment opportunity sets employ a larger proportion of short-term debt. Chen, Ho and Yeo (1999) documented a negative relationship between debt maturity and growth opportunities. Additionally, Stephan, Talaverab and Andriy (2011) found that unconstrained firms with greater opportunities use less long-term debt. Moreover, as indicated by Pour and Lasfer (2014), long-term debt maturity structures will significantly intensify the agency conflicts between creditors and shareholders, especially when the refinancing risk is considerable owing to rollover losses (Almeida, Campello, Laranjeira, \& Weisbenner, 2011; Li, 2012).

However, Villalonga et al. (2015) argue that the divergence of interests between shareholders and creditors is less grave in family firms than in non-family ones, because, as Anderson et al. (2003) indicate, the family shareholders' objectives of ensuring the long-term survival of the firm, preserving the family's reputation, keeping the firm in the family, along with the undiversified character of their investment, tend to encourage family firms to maximize firm value as a whole, rather than simply focusing on shareholder value. Coherently, Croci et al. (2011) contend that family shareholders will have an incentive to avoid risky investments, as most of their wealth is invested in the family firm. The authors also observe that this risk aversion is perceived by the credit markets, which mitigates owner-lender agency conflicts and makes long-term debt cheaper. For this reason, family firms will use more long-term debt than non-family ones. Therefore, thanks to the scarce presence of conflicts of interest between shareholders and creditors, family businesses can acquire long-term debt to finance long-term growth opportunities (Domenichelli, 2015). In line with this reasoning, Croci et al. (2011) also found that founder-run firms, where the magnitude of control is more noticeable, are considered to be less risky, and creditors are, therefore, willing to lend them long-term financial resources at more favourable terms.

\section{Conclusions}

The purpose of this article was to analyse and comment on the role of agency conflicts and the socioemotional orientation of family firms for their debt maturity structures. This issue was considered in light of the different relationships that are possible between groups of stakeholders, as described and studied by the corporate finance literature, namely, those between owners and managers; majority and minority shareholders, and family shareholders and family outsiders; and owners and creditors.

In the context of both socioemotional wealth and the owner-manager linkage, family firms may appear to be oriented toward certain aspects that are, at least to some extent, contrary to the achievement of value creation, e.g., the appointment of family members without proper impartial selection, so listed family businesses may need to signal their quality and validity to their lenders, that can thus provide, more easily, riskier long-term debt. This issue is worth investigating further to assess, for example, the relationship between independent and professional directors and managers and the debt maturity structure of family businesses, as well as the cost of debt capital. From an agency point of view, the conflict in question is alleviated thanks to large family shareholders' greater 
possibilities and incentives to monitor managers, which can lead to less frequent debt renewals. However, agency conflicts between owners and managers can be high in family firms when there is private ownership, thereby reducing external governance mechanisms. Moreover, whereas in first-generation family firms these agency conflicts are insignificant owing to the coincidence of ownership and management, in later-generation family businesses, where ownership and management become more dispersed, the agency conflicts between owners and managers grow. As a result, selfish managers prefer long-term debt so as to avoid the potential discipline of external monitoring.

If we look at the agency conflicts between majority family shareholders and minority shareholders, which are likely to be considerable in family firms, long-term debt may be used to limit the employment of personal resources for controlling shareholders and to consolidate their excess control rights. However, majority family shareholders show a lower motivation for expropriating minority shareholders, because of their socioemotional orientation which incentivizes them to pass on the business to their heirs and sustain the family reputation and image. When it comes to considering the relationship between family shareholders and family outsiders, the former may wish to raise significant amounts of short-term debt to signal to current and potential creditors especially in the absence of or given a weak discipline role of the market for corporate control - that their objective is not, or at least not only, the enhancement of the socioemotional wealth of their business, but rather the achieving of value generation.

Lastly, this examination concentrated on the relationships between creditors and owners, wherein there is room for the latter to engage themselves in activities, such as overinvestment or underinvestment in the presence of outstanding debt contracts, which can favour them to the detriment of the lenders. However, family firms are little influenced by the opportunistic behaviour of their owners, since their socioemotional orientation, together with the undiversified nature of their investments promote the long-term survival of the firm, the preservation of the family's reputation, and full perpetuation of family control. In turn, these goals make it possible for family firms to acquire substantially cheaper long-term debt to finance their long-term investments.

Based on the analysis of the relevant literature on the topic, even the most recent contributions, much still remains to be empirically studied. One interesting issue to explore further would be if and to what extent the influence of country-specific factors worldwide, in combination with firm-specific characteristics relating to agency conflicts and socioemotional wealth, can further explain the debt maturity decisions in family firms, compared to non-family firms. Highly reliable and perhaps even unique datasets should be preferably employed to adequately address these issues. In fact, comprehensive information on the ownership structures is needed (concerning, for example, family versus non-family managers and directors; the characteristics of blockholder ownership; a family generation leading the company; ultimate shareholders for pyramid structures). Therefore, further investigation in this field will have to possibly use these kinds of data, as their lack can lead to incomplete or misleading interpretations and prevent the most useful comparisons and validations.

Finally, additional results in this field can indeed shed new light on those specific country-related factors that may either expand or limit the development of family firms. This issue is a crucial one to examine because family-controlled businesses are a major source of value creation and social cohesion, given their widespread presence and activity worldwide, as previously described in this paper. In turn, this suggested analysis may lead governments to adopt specific policy measures, that will better support family businesses, in light of their peculiar and unique economic and non-economic aspects.

\section{References}

Ali, A., Chen, T. Y., \& Radhakrishnan, S. (2007). Corporate disclosures by family firms. Journal of Accounting and Economics, 44(1-2), 238-286. https://doi.org/10.1016/j.jacceco.2007.01.006

Almeida, H., Campello, M., Laranjeira, B., \& Weisbenner, S. (2011). Corporate debt maturity and the real effect of the 2007 credit crisis, Critical Finance Review, 1(1), 3-58. https://doi.org/10.1561/104.00000001

Amihud, Y., \& Lev, B. (1981). Risk Reduction as a Managerial Motive for Conglomerate Mergers. The Bell Journal of Economics, 12(2), 605-617. https://doi.org/10.2307/3003575

Amore, M. D., Minichilli, A., \& Corbetta, G. (2011). How do managerial successions shape corporate financial policies in family firms? Journal of Corporate Finance, 17(4), 1016-1027. https://doi.org/10.1016/j.jcorpfin.2011.05.002

Anderson, R. C., Duru, A., \& Reeb, D. M. (2012). Investment policy in family controlled firms. Journal of Banking \& Finance, 36(6), 1744-1758. https://doi.org/10.1016/j.jbankfin.2012.01.018

Anderson, R. C., Mansib, S. A., \& Reeb, D. M. (2003). Founding family ownership and the agency cost of debt. 
Journal of Financial Economics, 68(2), 263-285. https://doi.org/10.1016/S0304-405X(03)00067-9

Anderson, R. C., \& Reeb, D. M. (2003). Founding-Family Ownership and Firm Performance: Evidence from the S\&P 500. Journal of Finance, 58(3), 1301-1328. https://doi.org/10.1111/1540-6261.00567

Andres, C. (2008). Large shareholders and firm performance-An empirical examination of founding-family ownership. Journal of Corporate Finance, 14(4), 431-445. https://doi.org/10.1016/j.jcorpfin.2008.05

Astrachan, J. H., Klein, S. B., \& Smyrnios, K. X. (2002). The F-PEC Scale of Family Influence: A Proposal for Solving the Family Business Definition Problem. Family Business Review, 15(1), 45-58. https://doi.org/10.1111/j.1741-6248.2002.00045.x

Astrachan, J. H., \& Shanker, M. C. (2003). Family businesses' contribution to the U.S. economy: a closer look. Family Business Review, 16(3), 211-219. https://doi.org/10.1177/08944865030160030601

Barclay, M. J., \& Smith, C. W. Jr. (1995). The Maturity Structure of Corporate Debt. The Journal of Finance, 50(2), 609-631. https://doi.org/10.1111/j.1540-6261.1995.tb04797.x

Barnea, A., Haugen, R. A., \& Senbet, L. W. (1980). A rationale for debt maturity structure and call provisions in the agency theory framework. The Journal of Finance, 35(5), 1223-1234. https://doi.org/10.1111/j.1540-6261.1980.tb02205.x

Barontini, R., \& Caprio, L. (2006). The Effect of Family Control on Firm Value and Performance: Evidence from $\begin{array}{llll}\text { Continental Europe. European Financial Management, } & \text { 12(5), 689-723. }\end{array}$ https://doi.org/10.1111/j.1468-036X.2006.00273.x

Barth, E., Gulbrandsen, T., \& Schøne, P. (2005). Family ownership and productivity: The role of $\begin{array}{lllll}\text { owner-management. Journal of Corporate } & \text { Finance, 11(1), }\end{array}$ https://doi.org/10.1016/j.jcorpfin.2004.02.001

Bebchuk, L. A., Kraakman, R., \& Triantis, G. (2000). Stock Pyramids, Cross-Ownership, and Dual Class Equity: The Mechanisms and Agency Costs of Separating Control from Cash-Flow Rights. In R. K. Morck (Ed.), Chapter in NBER book Concentrated Corporate Ownership (pp. 295-318). University of Chicago Press. Retrieved from http://www.nber.org/chapters/c9013

Becker, G. S. (1974). Theory of Social Interactions. The Journal of Political Economy, 82(6), 1063-1093. https://doi.org/10.1086/260265

Benavides-Velasco, C. A., Quintana-García, C., \& Guzmán-Parra, V. F. (2013). Trends in family business research. Small Business Economics, 40(1), 41-57. https://doi.org/10.1007/s11187-011-9362-3

Berle, A., \& Means, G. (1932). The Modern Corporation and Private Property. New York: Mcmillan.

Blanco-Mazagatos, V., de Quevedo-Puente, E., \& Castrillo, L. A. (2007). The Trade-Off Between Financial Resources and Agency Costs in the Family Business: An Exploratory Study. Family Business Review, 20(3). https://doi.org/10.1111/j.1741-6248.2007.00095.x

Brailsford, T. J., Oliver, B. R., \& Pua, S. L. H. (2002). On the relation between ownership structure and capital structure. Accounting and Finance, 42(1), 1-26. https://doi.org/10.1111/1467-629X.00001

Burkart, M., Panunzi, F., \& Shleifer, A. (2003). Family Firms. The Journal of Finance, 58(5), 2167-2201. https://doi.org/10.1111/1540-6261.00601

Cai, C. X., Hillier, D., \& Wang, J. (2016). The Cost of Multiple Large Shareholders. Financial Management, 45(2), 401-430. https://doi.org/10.1111/fima.12090

Carney, M. (2005). Corporate Governance and Competitive Advantage in Family-Controlled Firms. Entrepreneurship Theory and Practice, 29(3), 249-265. https://doi.org./10.1111/j.1540-6520.2005.00081.x

Chahine, S. (2007). Block-holder ownership, family control and post-listing performance of French IPOs. Managerial Finance, 33(6), 388-400. https://doi.org/10.1108/03074350710748740

Chen, S., Chen, X., \& Cheng, Q. (2008). Do Family Firms Provide More or Less Voluntary Disclosure? Journal of Accounting Research, 46(3), 499-536. https://doi.org./10.1111/j.1475-679X.2008.00288.x

Chen, S. S., Ho, K. W., \& Yeo, G. H. (1999). The Determinants of Debt Maturity: the Case of Bank Financing in Singapore. Review of Quantitative Finance and Accounting, 12(4), 341-350. https://doi.org/10.1023/A:1008398308408

Chen, C. X., Lu, H., \& Sougiannis, T. (2012). The Agency Problem, Corporate Governance, and the 
Asymmetrical Behaviour of Selling, General, and Administrative Costs. Contemporary Accounting Research, 29(1), 252-282. https://doi.org/10.1111/j.1911-3846.2011.01094.x

Cheng, Q. (2014). Family firm research - A review. China Journal of Accounting Research, 7(3), 149-163. https://doi.org/10.1016/j.cjar.2014.03.002

Childs, P. D., Mauerb, D. C., \& Steven, H. (2005). Interactions of corporate financing and investment decisions: The effects of agency conflicts. Journal of Financial Economics, 76(3), 667-690. https://doi.org/10.1016/j.jfineco.2004.06.012

Chrisman, J. J., Chua, J. H., \& Litz, R. (2004). Comparing the agency costs of family and non-family firms: conceptual issues and exploratory evidence. Entrepreneurship Theory and Practice, 28(4), 335-354. https://doi.org/10.1111/j.1540-6520.2004.00049.x

Chrisman, J. J., Steier, L. P., \& Chua, J. H. (2008). Toward a theoretical basis for understanding the dynamics of strategic performance in family firms. Entrepreneurship Theory and Practice, 32(6), 935-947. https://doi.org/ 10.1111/j.1540-6520.2008.00264.x

Chua, J. H., Chrisman, J. J., \& Bergiel, E. B. (2009). An agency theoretic analysis of the professionalized family $\begin{array}{llll}\text { firms. } \quad \text { Entrepreneurship } \quad \text { Theory and } & \text { Practice, } 355-372 .\end{array}$ https://doi.org/10.1111/j.1540-6520.2009.00294.x

Claessens, S., Djankov, S., Fan, J. P. H., \& Lang, L. H. P. (2002). Disentangling the incentive and entrenchment effects of large shareholdings. The Journal of Finance, 57(6), 2379-2408. https://doi.org/10.1111/1540-6261.00511

Corbetta, G. (1995). Patterns of development of family businesses in Italy. Family Business Review, 8(4), 267-291. https://doi.org/10.1111/j.1741-6248.1995.00255.x

Croci, E., Doukas, J. A., \& Gonenc, H. (2011). Family Control and Financing Decisions. European Financial Management, 17(5), 860-897. https://doi.org/10.1111/j.1468-036X.2011.00631.x

Daily, C. M., \& Dollinger, M. J. (1992). An Empirical Examination of Ownership Structure in Family and Professionally Managed Firms. Family Business Review, 5(2), 117-136. https://doi.org/10.1111/j.1741-6248.1992.00117.x

Dang, V. A., \& Phan, H. V. (2016). CEO inside debt and corporate debt maturity structure. Journal of Banking \& Finance, 70, 38-54. https://doi.org/10.1016/j.jbankfin.2016.05.009

Datta, S., Iskandar-Datta. M., \& Raman, K. (2005). Managerial Stock Ownership and the Maturity Structure of

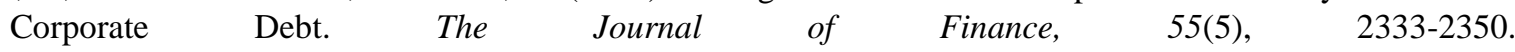
https://doi.org/10.1111/j.1540-6261.2005.00800.x

Debicki, B. J., Matherne, C. F., Kellermanns, F. W., \& Chrisman, J. J. (2009). Family business research in the new millennium. Family Business Review, 22(2), 151-166. https://doi.org/10.1177/0894486509333598

Díaz-Díaz, N. L., García-Teruel, P. J., \& Martínez-Solano, P. (2016). Debt maturity structure in private firms: Does the family control matter? Journal of Corporate Finance, 37, 393-411. https://doi.org/10.1016/j.jcorpfin.2016.01.016

Domenichelli, O. (2015). An Empirical Investigation of the Debt Maturity of Italian Family Firms. International Journal of Finance and Accounting, 4(5), 281-292. https://doi.org/10.5923/j.ijfa.20150405.06

Dyck, A., \& Zingales, L. (2004). Private Benefits of Control: An International Comparison. The Journal of Finance, 59(2), 537-600. https://doi.org/10.1111/j.1540-6261.2004.00642.x

Dyer, W. G. Jr. (2006). Examining the "Family Effect" on Firm Performance. Family Business Review, 19(4), 253-273. https://doi.org/10.1111/j.1741-6248.2006.00074.x

Eisenhardt, K. M. (1989). Agency Theory: An Assessment and Review. The Academy of Management Review, 14(1), 57-74. https://doi.org/10.5465/AMR.1989.4279003

Faccio, M., \& Lang L. H. P. (2002). The ultimate ownership of Western European corporations. Journal of Financial Economics, 65, 365-395. https://doi.org/10.1016/S0304-405X(02)00146-0

Fama, E. F., \& Jensen, M. C. (1983a). Separation of Ownership and Control. Journal of Law and Economics, 26(2), 301-325. https://doi.org/10.1086/467037

Fama, E. F., \& Jensen, M. C. (1983b). Agency Problems and Residual Claims. Journal of Law and Economics, 26(2), 327-349. https://doi.org/10.1086/467038 
Florackis, C., \& Ozkan, A. (2009). Managerial incentives and corporate leverage: evidence from the United Kingdom. Accounting and Finance, 49(3), 531-553. https://doi.org/10.1111/j.1467-629X.2009.00296.x

Floren, R. H. (1998). The significance of family business in the Netherlands. Family Business Review, 11(2), 121-134. https://doi.org/10.1111/j.1741-6248.1998.00121.x

Friend, I., \& Lang, L. H. (1988). An Empirical Test of the Impact of Managerial Self-Interest on Corporate Capital Structure. The Journal of Finance, 43(2), 271-281. https://doi.org/10.1111/j.1540-6261.1988.tb03938.x

Gomez-Mejia, L. R., Cruz, C., Berrone, P., \& De Castro, J. (2011). The Bind that Ties: Socioemotional Wealth Preservation in Family Firms. The Academy of Management Annals, 5(1), 653-707. https://doi.org/10.1080/19416520.2011.593320

Gomez-Mejia, L. R., Takacs-Haynes, K., Nuñez-Nickel, M., Jacobson, K. J. L., \& Moyano-Fuentes, J. (2007). Socioemotional wealth and business risks in family-controlled firms: Evidence from Spanish olive oil mills. Administrative Science Quarterly, 52(1), 106-137. https://doi.org/10.2189/asqu.52.1.106

International Family Enterprise Research Academy (IFERA). Family Businesses Dominate. Family Business Review, 16(4), 235-240. https://doi.org/10.1177/08944865030160040201

Jensen, M. C. (1986). Agency Costs of Free Cash Flow, Corporate Finance, and Take-overs. The American Economic Review, 76(2), 323-329. https://doi.org/10.2307/1818789

Jensen, M. C., \& Meckling W. H. (1976), Theory of the firm: managerial behaviour, agency costs and ownership structure. Journal of Financial Management, 305-360. https://doi.org/10.1016/0304-405X(76)90026-X

Jiraporn, P., \& Kitsabunnarat, P. (2007). Debt Maturity Structure, Shareholder Rights, and Corporate Governance. Working paper retrieved from http://ssrn.com/abstract=999265.

Johnson, S., La Porta, R., Lopez-De-Sinales, F., \& Shleifer, A. (2000). Tunnelling. AEA papers and proceedings, 90(2), 22-27. https://doi.org/10.1257/aer.90.2.22

Kalm, M., \& Gomez-Mejia, L. R. (2016). Socioemotional wealth preservation in family firms. Revista de Administração 51(4), 409-411. https://doi.org/10.1016/j.rausp.2016.08.002

Klein, S. B. (2000). Family businesses in Germany: significance and structure. Family Business Review, 13(3), 157-82. https://doi.org/10.1111/j.1741-6248.2000.00157.x

La Porta, R., Lopez-De-Silanes, F., \& Shleifer A. (1999). Corporate Ownership Around the World. The Journal of Finance, 54(2), 471-517. https://doi.org/10.1111/0022-1082.00115

Li, B. (2012). Refinancing Risk, Managerial Risk Shifting, and Debt Covenants: An Empirical Analysis, Queen's University. $\quad$ Retrieved from http://cn.ckgsb.com/Userfiles/doc/Refinancing\%20Risk,\%20Managerial\%20RiskShifting\%20and\%20Debt $\% 20$ Covenants $\% 20 \mathrm{An} \% 20$ Empirical\%20Analysis.pdf

Lopez-Gracia, J., \& Mestre-Barberá, R. (2015). On the Relevance of Agency Conflicts in SME Debt Maturity Structure. Journal of Small Business Management, 53(3), 714-734. https://doi.org/10.1111/jsbm.12083

McConnell, J. J., \& Servaes, H. (1990). Additional evidence on equity ownership and corporate value. Journal of Financial Economics, 27(2), 595-612. https://doi.org/10.1016/0304-405X(90)90069-C

Milton, L. P. (2008). Unleashing the relational power of family firms: identity confirmation as a catalyst for performance. Entrepreneurship Theory and Practice, 32(6), 1063-1081. https://doi.org/10.1111/j.1540-6520.2008.00273.x

Myers S. C. (1977). Determinants of Corporate Borrowing, Journal of Financial Economics, 5(2), 147-175. https://doi.org/10.1016/0304-405X(77)90015-0

Naldi, L., Cennamo, C., Corbetta, G., \& Gomez-Mejia, L. (2013). Preserving Socioemotional Wealth in Family Firms: Asset or Liability? The Moderating Role of Business Context. Entrepreneurship Theory and Practice, 37(6), 1341-1360. https://doi.org/10.1111/etap.12069

Pour, E. K., \& Lasfer, M. (2014). Taxes, Governance, and Debt Maturity Structure. Retrieved from http://www.efmaefm.org/0EFMAMEETINGS/EFMA\%20ANNUAL\%20MEETINGS/2014Rome/papers/E FMA2014_0243_fullpaper.pdf

Poza, E. (2007). Family Business, 2/e. Mason (OH): Thomson South-Western. 
PricewaterhouseCoopers (2007). The PricewaterhouseCoopers Family Business Survey 2007/08. Retrieved from https://www.pwc.co.za/en/assets/pdf/pwc-family-business-survey-08.pdf

Rajan, R., \& Winton, A. (1995). Covenants and Collateral as Incentives to Monitor. The Journal of Finance, 50(4), 1113-1146. https://doi.org/10.2307/2329346

Rogoff, E. G., \& Heck, R. K. Z. (2003). Evolving research in entrepreneurship and family business: Recognizing family as the oxygen that feeds the fire of entrepreneurship. Journal of Business Venturing, 18(5), 559-566. https://doi.org/10.1016/S0883-9026(03)00009

Sacristán-Navarro, M., Gómez-Ansón, S., \& Cabeza-García, L. (2011). Family Ownership and Control, the Presence of Other Large Shareholders, and Firm Performance: Further Evidence. Family Business Review 24(1), 71-93. https://doi.org/10.1177/0894486510396705

Schulze, W. S., Lubatkin, M. H., Dino, R. N., \& Buchholtz, A. K. (2001). Agency Relationships in Family Firms: Theory and Evidence. Organization Science 12(2), 99-116. https://doi.org/10.1287/orsc.12.2.99.10114

Sharma P. (2003). Stakeholder Mapping Technique: Toward the Development of a Family Firm Typology. Retrieved from https://www.wilfridlaurieruniversity.ca/documents/842/2003-01-MOB.pdf

Shleifer, A., \& Vishny, R. W. (1986). Large Shareholders and Corporate Control. Journal of Political Economy, 94(3), 461-488. https://doi.org/10.1086/261385

Shleifer, A., \& Vishny, R. W. (1989). Management Entrenchment. The Case of Manager-Specific Investments. Journal of Financial Economics, 25(1), 123-139. https://doi.org/10.1016/0304-405X(89)90099-8

Shyu, Y. W., \& Lee, C. I. (2009). Excess Control Rights and Debt Maturity Structure in Family-Controlled Firms. Corporate Governance: An International Review, 17(5), 611-628. https://doi.org/10.1111/j.1467-8683.2009.00755.x

Steier, L. P., Chua, J. H., \& Chrisman, J. J. (2009). Embeddedness perspectives of economic action within family firms. Entrepreneurship Theory and Practice, 33(6), 1157-1167. https://doi.org/10.1111/j.1540-6520.2009.00338.x

Stephan, A., Talaverab, O., \& Andriy, T. (2011). Corporate debt maturity choice in emerging financial markets. Quarterly Review of Economics and Finance, 51(2), 141-151. https://doi.org/10.1016/j.qref.2010.12.003

Straska, M., \& Waller, H. G. (2014). Antitakeover Provisions and Shareholder Wealth: A Survey of the Literature. Journal of Financial and Quantitative Analysis, 49(4), 933-956. https://doi.org/10.1017/S0022109014000532

Stulz, M. R. (2000). Does financial structure matter for economic growth? A corporate finance perspective. Working paper. Retrieved from https://pdfs.semanticscholar.org/aa58/0a352d5fd4e0747dfab3fee217b97591a609.pdf

Sun, J., Ding, L., Guo, J. M., \& Li, Y. (2016). Ownership, capital structure and financing decision: Evidence from the UK. The British Accounting Review, 48(4), 448-463. https://doi.org/10.1016/j.bar.2015.04.001

Villalonga, B., \& Amit, R. (2006). How do family ownership, control and management affect firm value? Journal of Financial Economics, 80(2), 385-417. https://doi.org/10.1016/j.jfineco.2004.12.005

Villalonga, B., \& Amit, R. (2009). How Are U.S. Family Firms Controlled? Review of Financial Studies, 22(8), 3047-3091. https://doi.org/10.1093/rfs/hhn080

Villalonga, B., \& Amit, R. (2010). Family Control of Firms and Industries. Financial Management, 39(3), 863-904. https://doi.org/10.1111/j.1755-053X.2010.01098.x

Villalonga, B., Amit, R., Trujillo, M. A., \& Guzmán, A. (2015). Governance of Family Firms. Annual Review of Financial Economics, 7, 635-654. https://doi.org/10.1146/annurev-financial-110613-034357

World Economic Forum. (2013). A Primer on Governance of the Family Enterprise. Retrieved from https://faculty.wharton.upenn.edu/wp-content/uploads/2013/09/WEF_FPC_FamilyEnterpriseGovernance_R eport_1.pdf

Zahra, S. A., Hayton, J. C., Neubaum, D. O., Dibrell, C., \& Craig, J. (2008). Culture of family commitment and strategic flexibility: the moderating effect of stewardship. Entrepreneurship Theory and Practice, 32(6), 1035-1054. https://doi.org/10.1111/j.1540-6520.2008.00271.x

Zellweger, T. M., Nason, R. S., Nordqvist, M., \& Brush, C. G. (2011). Why Do Family Firms Strive for Nonfinancial Goals? An Organizational Identity Perspective. Entrepreneurship Theory and Practice, 37(2), 
229-248. https://doi.org/10.1111/j.1540-6520.2011.00466.x

\section{Notes}

Note 1. For further international data and comparisons concerning family businesses belonging to about 25 countries, see International Family Enterprise Research Academy (IFERA) (2003).

\section{Copyrights}

Copyright for this article is retained by the author(s), with first publication rights granted to the journal.

This is an open-access article distributed under the terms and conditions of the Creative Commons Attribution license (http://creativecommons.org/licenses/by/4.0/). 